course too would have given the litigants an opportunity for full argument of the crucial issue.

Moreover, there is more at stake in the policy of allowing full argument than interests of the litigants in a particular dispute. While historically the judiciary has been restricted to the determination of issues arising out of litigation between two parties, judicial decisions even within these limits obviously affect the rights of others similarly situated. They may also influence important economic and political trends. To the extent that there is justified fear in allowing a non-elective body to exercise this power, it is cause for concern when the Supreme Court-even where on the surface a full-dress argument seems pointless-pronounces final judgment on issues which representative litigants have not had a chance to contest.

\title{
POWER TO STAY FEDERAL PROCEEDINGS PENDING TERMINATION OF CONCURRENT STATE LITIGATION*
}

STATE courts have long exercised discretionary power to stay proceedings where a suit involving the same parties and issues is already under way in another forum. ${ }^{1}$ Stays are customarily ordered on grounds of comity, ${ }^{2}$ or,

(judgment reversed and cause remanded to state supreme court for reconsideration of the question whether petitioner's conviction had been affirmed on basis of section of statute different from that section under which he had been tried); Musser v. Utah, 333 U.S. 95 (1948) (to afford the state supreme court an opportunity to deal with issue of federal law by interpreting state statute under which petitioner was convicted, causc remanded); Von Moltke v. Gillies, 332 U.S. 708 (1948) (cause remanded to district court for further hearings to decide whether petitioner pleaded guilty in reliance upon the erroneous legal advice of a Government agent); Stromberg v. California, 283 U.S. 359 (1931); Mahler v. Eby, 264 U.S. 32, 45 (1924) (reversed with orders not to discharge petitioner until respondent corrected and perfected his findings as requircd by statute).

* Mottolese v. Kaufman, 176 F.2d 301 (2d Cir. 1949).

1. Stays are ordered regardless of the jurisdiction in which the prior stit lies and without respect to the parties' positions as plaintiff or defendant in the earlier proceeding. E.g., Oppenheimer v. Carabaya Rubber \& Nav. Co., 145 App. Div. 830, 130 N.Y. Supp. 587 (1st Dep't 1911) (favored action in foreign country) ; De La Vergne Mach. Co. $v$. New York \& B. Brewing Co., 125 App. Div. 649, 110 N.Y. Supp. 24 (2d Dep't 1908) (parties reversed in second controversy in same state); Allentown Foundry \& Machinc Works v. Loretz, 16 App. Div. 72, 44 N.Y. Supp. 689 (2d Dep't 1897) (same plaintiff in courts of different states); $R e$ Phelan, 225 Wis. 314, 274 N.W. 411 (1937) (same plaintiff in federal and state courts in different states).

"[T]here is no technical rule that the issues and parties must be identical in all respects in order that the trial in one action may be stayed . . . until after the trial of the other." De La Vergne Mach. Co. v. New York \& B. Brewing Co., supra, at 650, 110 N.Y. Supp. at 25 (extra incidental issue requiring additional party in suspended action might never be reached); cf. Vaughan v. Wayne Circuit Judge, 153 Mich. 478, 116 N.W. 
more practically, to avoid unnecessary burdens on courts and defendants. ${ }^{3}$ Federal courts likewise grant stays in deference to an earlier action. But, as a general rule, they do so only where both suits are pending in federal forums." Where the prior action is in a state court, practical reasons for granting

1086 (1908). Stays of suits involving different individuals in privity with each other are often granted. E.g., Shanik v. Aller, 268 Agp. Div. 1007, 1008 (2d Dep't 1944) (derivative shareholder suits). Peacock v. Lutz \& S. Co., 171 App. Div. 256, 157 N.Y. Supp. 175 (1st Dep't 1916) (assignor and assignee pressing separate actions on same claim) ; Milvy v. Sperry Corp., 36 N.Y.S.2d 881 (Sup. Ct. 1939) (actions by voting trust certificate holders).

Aithough it is the subsequent action which is ordinarily stayed, circumstances may occasionally warrant stay of an earlier suit. E.g., Levy v. Pacific Eastern Corp., 154 Misc. 655, 277 N.Y. Supp. 659 (Sup. Ct. 1935) (action with two days priority staycd where second suit will very likely reach judgment first).

See, generally, Note, 81 L. Ed. 161 (1937). A stay where the same parties and issues are involved in both suits is closely analogous to a defendant's right to abate the second of two actions brought by the same party against him for the same cause in the same state jurisdiction. Clark, Code Plaading \$95 (2d ed. 1947); Sulparan, Cosnro:i-Law Preadivg \$225 (3d ed., Ballantine, 1923). Abatement, which completely defeats the later suit, forces the parties to accept adjudication of their claims in the favored suit because of familiar principles of res judicata. And an order to stay, while merely suspending proceedings, likewise restricts the parties unless the stay is subsequently vacated and decision is reached before judgment in the earlier action.

2. See, e.g., Levy v. Pacific Eastern Corp., 154 Misc. 655, 657, 277 N.Y. Supp. 659, 662 (Sup. Ct. 1935) ; cf. Klanian v. New York Life Ins. Co., 39 F. Supp. 777,778 (D.R.I. 1941).

3. See, e.g., Lowenstein v. Diamond Soda Water Mfg. Co., 94 App. Div. 383, 385-6, 88 N.Y. Supp. 313, 315-16 (1st Dep't 1904); Allentown Foundry \& 1schine Worlss v. Loretz, 16 App. Div. 72, 73, 44 N.Y. Supp. 6S9, 690 (2d Dep't 1897) ; Levy v. Pacific Eastern Corp., 154 Misc. 655, 657-8, 277 N.Y. Supp. 659, 663 (Sup. Ct. 1935).

4. Stays of federal actions in deference to duplicate federal proceedings are granted under the same general circumstances and for the same practical reasons which give rise to stays of state actions, see notes 1 and 3 supra. E.g., Schwartz v. Kaufman, 46 F. Supp. 318 (E.D.N.Y. 1940); Ryan v. Seaboard \& R. R.R., S9 Fed. 397 (C.C.E.D. Va. 1898) ; Hurd v. Moiles, 28 Fed. $\$ 97$ (C.C.W.D. Mich. 1886); cf. United States v. Standard Oil Co., 7 F.R.D. 338 (S.D. Cal. 1947). The Supreme Court has brosdly defined the power to stay to include the right to suspend proceedings even where plaintifis in the halted suit are not represented in the favored suit but, practically, would be largely precluded by its decision. See Landis v. North American Co., 299 U.S. 248, 255 (1936) ; Kansas City Southern Ry. v. United States, 282 U.S. 760, 763-4 (1931).

A rule of abatement similar to that adopted in the state courts, see note 1 supro, is generally applied by the federal courts where two federal actions are pending which are identical as to parties, subject matter and relief sought. See The Haytian Republic, 154 U.S. 118, 123-4 (1894) ; Insurance Co. v. Brune's Assignee, 96 U.S. 58S, $592-3$ (1878); cf. Johnson v. New York, O. \& W. Ry., 3 F. Supp. 80 (E.D.N.Y. 1931) (no abatement where actions in different districts under special statute); Ryan v. Seaboard \& R. R.R., supra, at 407-8 (query as to propriety, generally, of abatement where different distriets). But this rule is not applied as between federal and state courts. Stanton v. Embrey, 93 U.S. 548 (1877); General Outdoor Advertising Co. v. Williams, 12 F.2d 773 (1st Cir. 1926). See Gordon v. Gilfoil, 99 U.S. 168, 178 (1878). See, generally, 7 Cre. Fed. Proe. $\S \S 3221-8$ (2d ed. 1943). 
stays have been largely overlooked and the federal action is usually allowed to proceed. ${ }^{5}$.

The general refusal of federal courts to order stays in deference to earlier state proceedings rests on the supposed existence of an indefeasible "right" to federal trial: ordering a stay amounts to an unauthorized abandonment of federal jurisdiction to the state courts. ${ }^{6}$ This theory, originating in inauspicious dicta, ${ }^{7}$ has gained respectability through repetition. ${ }^{8}$

Yet the principle of an "absolute" right has not always been carried into practice. Thus, in order to avoid multiple suits, district courts have occasionally ignored the federal no-stay rule, ${ }^{9}$ even though the litigant was

5. E.g., Great North Woods Club v. Raymond, 54 F.2d 1017 (6th Cir. 1931) ; MCClelland v. Carland, 187 Fed. 915 (8th Cir. 1911); Woren v. Witherbee, Sherman \& Co., 240 Fed. 1013 (N.D.N.Y. 1917) ; see Kline v. Burke Const. Co., 260 U.S. 226, 234 (1922); cf. McClelland v. Carland, 217 U.S. 268 (1910); Armour \& Co. v. Miller, 91 F.2d 521 '(8th Cir. 1937).

Despite the weight of authority, federal district courts have not always followed this arbitrary "no stay" rule. See note 9 infra.

6. See, e.g., Kline v. Burke Const. Co., 260 U.S. 226, 234-5 (1922); Great North Woods Club v. Raymond, supre note 5 at 1018; Consumers Gas Trust Co. v. Quinby, 137 Fed. 882, 893-4 (7th Cir. 1905).

McClelland v. Carland, 217 U.S. 268 (1910), has been heavily relied on as supporting an absolute privilege to proceed to federal trial. While dicta in the case, $i d$. at 281-2, may be stretched to achieve this effect, it can be done only by ignoring the Court's explicit refusal to pass upon the validity of a stay when state proceedings are already under way at the time the federal action is launched. Id. at 282-3.

7. "The judiciary cannot, as the legislature may, avoid a measure, because it approaches the confines of the constitution. ... We have no more right to decline the exercise of jurisdiction which is given, than to usurp that which is not given. The onc or the other would be treason to the constitution." Cohens v. Virginia, 6 Wheat. 264, 403 (U.S. 1821).

8. See, e.g., Chicot County v. Sherwood, 148 U.S. 529, 534 (1893); Hyde v. Stone, 20 How. 170, 175 (U.S. 1857). And see cases cited note 6 supra.

9. Especially in recent years, stays in deference to state litigation based on practical considerations of justice have been granted. E.g., Prudential Ins. Co. v. Zimmerer, 66 F. Supp. 492 (D. Neb. 1946) ; Brendle v. Smith, 46 F. Supp. 522 (S.D.N.Y. 1942); Klanian v. New York Life Ins. Co., 39 F. Supp. 777 (D.R.I. 1941); Vowinckel v. N. Clark \& Sons, 162 Fed. 991 (C.C.N.D. Cal. 1908); see American Brake Shoe \& Foundry Co. v. Interborough Rapid Transit Co., 10 F. Supp. 512, 519 et seq. (S.D.N.Y. 1935), aff'd on opinion below, 76 F.2d 1002 (2d Cir. 1935), cert. denicd sub nom. New York City v. Murray, 295 U.S. 760 (1935). And the courts of appeal have likewise evidenced growing dissatisfaction with the rule. In fact, the ninth circuit has already spoken in language strongly suggestive of a general discretionary power to stay federal actions pending conclusion of state proceedings. See Butler v. Judge, 116 F.2d 1013 (9th Cir. 1941) ; cf. Aetna Casualty \& Surety Co. v. Abbott, 130 F.2d 40, 42 (4th Cir. 1942); Southern Pac. Co. v. Klinge, 65 F.2d 85, 86-7 (10th Cir. 1933); Hennessy v. Tacoma Smelting \& Refining Co., 129 Fed. 40, 45 (9th Cir. 1904). Even the Supreme Court, by implication in dictum, appears to have approved a power to stay in deference to state actions. For in Landis v. North American Co., 299 U.S. 248, 254-5 (1936), it referrcd to cases denying such stays on the "absolute right" theory, see Checker Cab Mfg. Co. v. Checker Taxi Co., 26 F.2d 752 (N.D. Ill. 1928); Wadleigh v. Veazie, 28 Fcd. Cas، 1320, 
thereby denied a federal forum. Similarly, the Supreme Court has endorsed the dismissal of a declaratory judgment action involving the same questions already at issue in a state court. ${ }^{10}$ And even where multiplicity was not the foremost consideration, the federal forum has frequently been closed, sharply contradicting a theory of absolute right. Federal courts, for example, have often dismissed or stayed equitable suits in order to avoid interfering with the administration of state laws ${ }^{11}$ or passing on the constitutionality of ambiguous state statutes. ${ }^{12}$ Admiralty relief has been similarly withheld in order to assure a jury trial in a state court ${ }^{13}$ or to relegate foreign litigants to a home forum. ${ }^{14}$ And actions involving the internal affairs of an

No. 17,031 (C.C.D. Mre. 1838), as acceptable only on the ground that "discretion was abused by a stay of indefinite duration in the absence of a pressing need."

An important exception to the general "no stay" rule exists in the case of concurrent actions of an essentially in rem character involving the same res. Because of the special nature of in rem jurisdiction, federal courts uniformly refuse to proceed to judgment when the state suit is earlier. Princess Lida of Thurn v. Thompson, 305 U.S. 456 (1939); sce Kline v. Burke Const. Co., 260 U.S. 226, 229-30 (1922). See Mrcone, Junicruz Cone COMIMIENTARY 404-5 (1949).

10. Brillhart v. Excess Ins. Co. of America, 316 U.S. 491 (1942). "Ordinarily it would be uneconomical as well as vexatious for a federal court to proceed in a declaratory judgment suit where another suit is pending in a state court presenting the same issues, not governed by federal law, between the same parties. Gratuitous interference with the orderly and comprehensive disposition of a state court litigation should be avoided." Id. at 495. See Note, 51 YaLe L.J. 511 (1942).

11. E.g., Burford v. Sun Oil Co., 319 U.S. 315 (1943) (complex state regulators; system for oil production); Great Lakes Dredge \& Dock Co. v. Huffman, 319 U.S. 293 (1943) (state fiscal policy); Beal v. Mlissouri P. R.R., 312 U.S. 45 (1941) (state criminal prosecution); Pennsylvania v. Williams, 294 U.S. 176 (1935) (liquidation of insolvent state bank under elaborate state administrative system); cf. Stainback v. Afo Hock Lol: Po, 336 U.S. 368, 383-4 (1949) (enforcement by injunction of territorial statute); Propper v. Clark, 337 U.S. 472, 489-92 (1949) ; Aleredith v. Winter Haven, 320 U.S. 228, 234-8 (1943). For discussion of such cases and of congressional enactments similarly restricting the scope of federal judicial interference with state functions, see Mfoone,

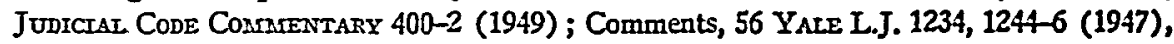
28 Texas L. Rev. 410 (1950).

12. E.g., Spector MIotor Service, Inc. v. MIcLaughlin, 323 U.S. 101 (1944); Railroad Comm'n v. Pullman Co., 312 U.S. 496 (1941); Gilchrist v. Interborough Rapid Transit Co., 279 U. S. 159 (1929) ; cf. Toomer v. Witsell, 334 U.S. 385 (1948). In Thompson v. Magnolia Petroleum Co., 309 U.S. 478 (1940), the Court required submission of an undecided question of state law to the state courts even where no constitutional issue was involved. Cf. In re President and Fellows of Harvard College, 149 F.2d 69, 72-3 (1st Cir. 1945); Propper v. Clark, 337 U.S. 472, 489-92 (1949); Meredith v. Winter Haven, 320 U.S. 22S, 234-38 (1943).

13. Langnes v. Green, 282 U.S. 531 (1931) (abuse of discretion where admiralty court failed to stay limitation of liability proceedings instituted subsequent to action for damages between same parties in state court).

14. Canada Malting Co. v. Patérson Steamships, Ltd., 285 U.S. 413 (1932) (discretion to dismiss though cause of action arose in domestic waters and the plaintiff would not recover full damages in home forum); Charter Shipping Co., Ltd. v. Bowring, Jones \& Tidy, Ltd., 281 U.S. 515 (1930) (similar). The statute vesting federal courts with ex- 
out-of-state corporation have been dismissed on the grounds of convenience and efficient administration of justice. ${ }^{15}$

In Mottolese $v$. Kaufman, ${ }^{16}$ the second circuit recently dealt an additional blow to the "absolute right" theory. With a state proceeding already under way, a federal suit had been brought under the guidance of the same attorneys against the same defendants on identical claims. ${ }^{17}$ Relying chiefly on principles of practical fairness which underlie forum non conveniens, ${ }^{18}$ the court affirmed the power to stay the federal suit. ${ }^{19}$

clusive admiralty jurisdiction does not provide for such dismissal of actions between foreigners. 28 U.S.C. § 1333 (1949).

Federal courts have also occasionally exercised a power to dismiss actions at law brought on a foreign cause of action. Heine v. New York Life Ins. Co., 50 F.2d 382 (9th Cir. 1931). See Comment, 56 YALE L.J. 1234, 1242-3 (1947).

15. Rogers v. Guaranty Trust Co., 288 U.S. 123 (1933); see Note, 33 Col. L. Rev. 492 (1933). As applied in the Guaranty case, the internal affairs rule had the practical effect of depriving the plaintiff of all federal jurisdiction over most of the defendants. See the dissent by Justice Stone, 288 U.S. 123, 147. It was replaced by the less arbitrary forum non conveniens doctrine in Koster v. Lumbermens Mutual Casualty Co., 330 U.S. 518, 526-9 (1947). See note 18 infra.

16. 176 F.2d 301 (2d Cir. 1949).

17. The attorneys in control of these actions represented a majority of the plaintiffs in nine original suits which made up the consolidated action. These various state suits had been started from seven months to a year previous to the filing of the Mollolesc suit. Shortly after the first state action, a federal action similar to the Moltolese suit had been brought by the attorneys in the name of another plaintiff. 176 F.2d 301-2. This plaintiff had sought a dismissal of his action. Id. at 302. The Mottolese suit might, therefore, be explained as an attempt to protect the jurisdiction obtained in the earlier federal action. But adequate opportunity for such protection would seemingly have been afforded by intervention in the earlier suit.

18. See Gulf Oil Corp. v. Gilbert, 330 U.S. 501 (1947); Koster v. Lumbermens Casualty Co., 330 U.S. 518 (1947). For discussion of the doctrine and its background, see Barrett, The Doctrine of Fornm Non Conveniens, 35 Caurr. L. REv. 380 (1917); Braucher, The Inconvenient Federal Fornm, 60 HARv. L. Rev. 908 (1947); Comment, 56 YALE L.J. 1234 (1947).

As originally formulated by the Supreme Court, the doctrine established discretionary power to dismiss whenever the choice of forum caused undue inconvenience to court and litigants. Such dismissal could result in depriving the plaintiff of all access to federal jurisdiction. The difficulties of re-serving process might prevent a second federal action. And although another forum was in fact available in the Koster and Gulf cases, dismissal for inconvenience was not in terms conditioned upon accessibility of another federal forum. Hence dismissal might, in consequence of venue restrictions, result in denying the plaintiff effective recourse to the federal courts. This could occur where the only convenient forum lay outside the judicial district of the plaintiff's or defendant's residence.

These problems, however, will not arise under the new Judicial Code: dismissal is replaced by transfer to some more convenient district or division in which the action "might have been brought." 28 U.S.C. \$1404(a) (1949).

19. The court reasoned that the same burdening of defendants which warranted application of forum non conveniens equally sustained the stay of burdensome duplicato litigation. 176 F.2d 301, 303. In further support of the particular stay involved, it relied on the basic considerations motivating the use of consolidation and equitable intervention in avoiding multiplicity, see note 23 infra. 
There are sound reasons for the general power to stay adopted in the Mottolese decision. Any legal impediment has been effectively removed by progressive undermining of the "absolute right" theory of federal jurisdiction. Moreover, basic considerations which justify the present acceptance of stays where two federal actions are pending ${ }^{*}$ also apply in the case of an earlier state proceeding. One tribunal's expenditure of time and effort will prove wasted since the first decision will be res judicata in the other suit. ${ }^{21}$ The second action entails an added drain on the defendant's resources which may result in frustration of his legitimate claims or provide an unscrupulous party with a powerful weapon with which to force his opponent into an unfair settlement. ${ }^{22}$ Double actions also promote tactical maneuvering designed to delay the suit proceeding least favorably to the party's interests. ${ }^{23}$

Judge Frank, in dissenting, 176 F.2d 301, 304 et seq., did not clearly disaffirm complete use of the power to stay as a device for avoiding multiple suits in state and federal forums. He deemed the majority's reliance on forum non conveniens and equitable intervention unwarranted, however, and argued that the court erred in placing the burden of justifying continuation of the second suit upon the plaintiff. Thus, if Judge Franls were to acknowledge the power to stay, a conclusion which is not clear from his opinion, he would apparently feel that the burden should be upon the defendant to offer reasons in addition to multiplicity for discounting the federal suit.

Judge Frank further opposed the particular stay by pointing to several advantages of the federal forum: a probable earlier decision, superior pre-trial examination, sce note 32 infra, and greater protection of non-party shareholders by virtue of federal requirements of notice of all settlements and dismissals, see note 37 infro. The majority did modify its stay so as to allow for some advantages of federal jurisdiction. See discussion, pages $985-6$ infra.

20. See note 4 supra.

21. In allowing the action to proceed, the federal court normally protects only the contingency that final decision will be reached in that forum. Such a conjectural advantage certainly does not require absolute protection. Moreover, the fact that each forum administers the same substantive law, at least where both actions lie in the same state, see note 27 infra, makes the second suit seem all the more unnecessary.

22. Not only may the defendant be unable to finance the double suits, but his dual costs may exceed the value of the controverted claim. Burdens may also arise from mechanical difficulties of simultaneously running two parallel actions.

23. The efforts of courts to avoid the evils of multiple litigation are reflected not only in the granting of stays, but in resort to other judicial measures as well. Abatement has already been mentioned, see notes 1 and 4 stpra. See the discussions in Chicago, B. \& Q. R.R. v. Weil, 183 Fed. 956, 960-1 (8th Cir. 1911), and Smith v. Atlantic Mutual Fire Insurance Co., 22 N.H. 21, 23 (1850). Equity frequently assumes jurisdiction to prevent rexatious and expensive multiple suits. Sovereign Camp, W.O.W. v. O'Neill, 266 U.S. 292 (1924) ; see, Di Giovanni v. Camden Fire Ins. Ass'n, 296 U.S. 64, 70-1 (1935); Hale v. Allinson, 18s U.S. 56, 71-80 (1903). See 1 Posreroy, Equity JuRIsprudearce $\$ \$ 243-75$ (5th ed., Symons, 1941). And consolidation of related actions in the same court or jurisdiction is a common means of avoiding needless multiplicity. Dresdner $v$. Goldman Sachs Trading Corp., 240 App. Div. 242, 249-50, 269 N.Y. Supp. 360, 369, leave to appeal denied, 241 App. Div. 745 (2d Dep't 1934). See Fed. R. Crv. P. 42(a); 3 Moore \& Friedatan, Federai Practice $\$ 42.01$ (1938); Clare, Code Pleadrig $\$ 76$ (2d ed. 1947). 
In particular cases, however, it might be urged that special advantages of federal jurisdiction warrant denial of a stay despite these objectionable features of duplicate litigation. The federal action may provide more extensive discovery for thorough trial preparation, ${ }^{24}$ a speedier adjudication, ${ }^{26}$ or a simpler, more efficient procedure less apt to permit technical snarls. Occasionally there may be additional benefits: a more desirable judge, an opportunity for jury trial, ${ }^{26}$ a different rule of substantive law, ${ }^{27}$ or a forum

24. Deposition and discovery are provided by Federal Rules 26 to 37. Their clear philosophy of virtually unlimited discovery contrasts sharply with the confused and re* stricted patterns found in numerous states. Compare KocH, Deposirions AND DiscovemY UNDER THE Federat Rules (Practising Law Institute, Trial Practice Series Motlograph No. 8, 1946), with Dawson, Examinations Before Trial in State Courts (Practising Law Institute, Trial Practice Series Monograph No. 5, 1946). See also Eicuril AnnuaL Report of the Judictal Council of the State of New York, 363-6 (1942); Pike \& Willis, The New Federal Deposition-Discovery Procedure, 38 Cot. L. REv. 1178-98, 1436-43 (1938) ; Comment, Tactical Use and Abuse of Depositions, 59 YALE L.J. 117-121 (1949).

While federal practice respecting the use of evidence obtained through discovery generally resembles state procedure, occasional deviation from a particular state rule may afford a substantial benefit to the federal suitor. In the admissibility of depositions, for instance, advantages may derive from a different federal practice respecting such matters as impeachment of a party's own witnesses, requisite unavailability of witnesses at the trial, use of the opponent's deposition testimony or of the depositions taken by him, and use of parts of depositions. Fed. R. Civ. P. 26(d, f). See 2 Moore, Federal Practice $\$ 26.17$ (1st ed. 1938); Pike \& Willis, supra, at 1444-51. Compare Rule 26(d) (3) with the diverse state provisions collected in 5 WIGMORE, EVIDENCE $§ 1411 \mathrm{n} .1$ (3d ed. 1940).

25. A federal suit which is tried to the court may reach decision before an carlicr state action tried to a jury since there is typically a greater delay in reaching trial of jury cases. A similar variance in docket conditions between state and federal courts may occur even where both suits are tried to the court or to a jury. Thus, in New Yorle County a tort case presently requires 35 months to reach jury trial, N.X. Times, March 17, 1950 , p. 17 , col. 5 , whereas in the federal district court for that area jury trial can bo reached in 22 months, Communication to the YALE LAw Jourasu from Frank J. Gunner, Jr., Calendar Commissioner, United States District Court for the Southern District of New York, dated March 27, 1950, in Yale Law Library.

26. Pleadings in the state court may be so framed that all issues will be tricd to the court, whereas the same issues raised in the federal action may be triable to a jury. Thus a party's joinder of legal and equitable claims will "waive" jury trial in New York, Di Menna v. Cooper \& Evans Co., 220 N.Y. 391, 115 N.E. 993 (1917), but nat in the federal courts. Clark, Code Pleading $\$ 17$ (2d ed. 1947). And a defendant who interposes a legal counterclaim in an equitable action may "waive" jury trial on his legal claim in a state court, Behrens v. Kruse, 121 Minn. 28, 142 N.W. 118 (1913), althoughh he does not do so in the federal court. See Clark, op. cit. supra, §17. He mny secure a jury, however, by bringing a new action in the federal forum. See ibid.

27. When both forums lie in a single state, the same law will generally apply in each. But where the federal forum is in another state, a difference in applicable substantive law may result. This could occur, for example, where the states apply different conflicts of law rules or where two circuits have made conflicting rulings on the samo question of federal law. 
nearer to sources of proof. ${ }^{23}$ Moreover, in class actions, especially derivative shareholder suits, the prior state action may have been brought by a plaintiff who fails to prosecute diligently because of private settlement ${ }^{\mathfrak{D}}$ or collusion with the defendant. ${ }^{30}$ The federal proceeding may' then be essential to the fullest protection of class interests. ${ }^{31}$

The Mottolese case accepted the need for preserving such legitimate practical advantages of federal jurisdiction: the court decided that a stay was proper except if some reason appeared why the claim could not be as speedily and effectively prosecuted in the state action. Concluding that the only apparent advantage of the second action was the federal deposition machin-

28. A defendant may be purposely sued in a state forum which is quite burdensome because distant from necessary witnesses, evidence, etc, located in a different state. Yet forum non conveniens, which in the federal courts permits transfer to a more convenient forum, 28 U.S.C. $\$ 1404$ (a) (1949), is not generally applied in state courts where the convenient forum lies outside the state. See Barretr, supra note 18, at 393 . The defendant may extract himself from this predicament only if he can maintain suit in the nature of a counterclaim in a federal forum which is convenient or from which he can get a transfer to the preferable district.

Non-resident plaintiffs in diversity actions might seek removal to the federal forum because of the bias of a state judge or jury. Today, however, this traditional justification for diversity jurisdiction is rarely valid. See Friendly, The Hisloric Basis of Diversity Jurisdiction, 41 HARv. L. REv. 483, 510 (192S). The improbability of partiality is reflected in the failure of the new Judicial Code to retain prejudice or loeal influence as a basis for removal. 28 U.S.C. \$1441 (1949). See Reviser's Notzs, 23 U.S.C. Cong. SERv. 1441 (1948); MIOoRe, Judicial Code Coararentada 224-7 (1949).

29. The plaintiff-stockholder may be purposely suing to achieve a juicy "shalkedown" settlement which will frustrate legitimate corporate claims; or he may initiate suit with laudable intentions, but yield to an attractive offer of private settlement with a similar unfortunate result. See Dresdner v. Goldman Sachs Trading Corp., 240 App. Div. 242, 247-8, 269 N.Y. Supp. 360, 366-7, leave to appeal detied, 241 App. Div. 745 (2d Dep't 1934) ; Hornstein, Problems of Procedure in Stockholder's Dcrizative Suits, 42 CoL. L. Rev. 574, 583-4 (1942); Hornstein, Legal Conirols for Iniracorporalc Abusi-Present and Future, 41 CoL. L. REv. 405, 425-8 (1941) ; Note, 54 HARv. L. Rev. 833-7 (1941).

30. The collusive suit is a common technique whereby wrongdoers may defeat a corporate right of action against them: friendly stockholders are persuaded to sue, with the ultimate result that the suit is discontinued after the statute of limitations has run, or a consent judgment in favor of defendants is entered, or a court-approved settlement is reached which, though unfair, cannot be successfully attacked. See Dresdner v. Goldman Sachs Trading Corp., sipra note 29, at 247-S, 269 N.Y. Supp. at 367; Hornstein, Legal Controls for Intracorporate Abuse-Present and Future, 41 Col. L. REv. 405, 422, 426 (1941) ; MrcLaughlin, Capacity of Plainfiff-Stockholder to Terminate a Stockiholder's Suit, 46 YaLE L.J. 421, 426, 428,430 (1936).

31. Intervention by other shareholders in a derivative suit is a matter for judicial discretion; it may be denied if the judge fails to recognize any actual need for protection. See Barlanime, Corporations $\$ 153$ (rev. ed. 1946); Hornstein, Problenus of Procedure in Stockholder's Derivative Suits, 42 CoL. L. Rev. 574, 576-7 (1942). Even if intervention is allowed, the original parties' control may still continue. BALLnstrms, op. cit. suffro, \$153; Hornstein, supra, at 577. In either of these events, the federal forum may afford the outsiders their only chance effectively to prosecute their claims. See Dresdner $v$. Goldman Sachs Trading Corp., supra note 29, at 246, 269 N.Y. Supp. at 365-6. 
ery, ${ }^{32}$ the court approved defendants' motion for a stay only on condition that plaintiff be allowed to take depositions in the state action which would be equivalent to those permissible under the federal rules; or, if the defendants refused, that depositions be taken in the federal action and used in the state proceeding. The federal action would be revived, however, if the defendants objected to the use of these depositions in the state suit. ${ }^{33}$

Attractive on its face, this modification of the stay order is basically unsound. While federal discovery procedures serve a useful purpose, plaintiffs can use them to create expense, delay, and harassment. ${ }^{34}$ And abuse is especially likely where, as in the Mottolese case, the same attorneys are directing both class actions. ${ }^{35}$ Furthermore, the conditional stay encourages double actions brought solely to procure valuable federal discovery while avoiding undesirable aspects of a complete federal proceeding. ${ }^{36} \mathrm{~A}$ plaintiff

32. 176 F.2d 301, 303. But see note 19 supra. In contrast with the liberal federal practice, see note 24 supra, New York pre-trial examination is restricted and confused with respect to scope and persons examinable. See N.Y. Crv. PRAC. Acr \$288; Saxc, Examinations Before Trial in New York, 36 LAw LrB. J. 112 (1943). Such pre-trial examination can prove a special handicap in derivative shareholder suits. The complexity of these suits and the need to procure vital information from hostile witnesses places a great premium on the availability of complete discovery. Hayes, $A$ Shudy in Trial Tactics: Derivative Stockholders' Suits, 43 CoL. L. Rev. 275, 279-80 (1943); Hornstein, Legal Controls for Intracorporate Abuse-Present and Future, 41 Coc. L. REv. 405, 416-22 (1941).

33. 176 F.2d 301, 303-4.

Certain defendants in the state suit were not parties to the federal action. As observed by Judge Frank in his dissent, $i d$. at 309 , the first alternative would leave plaintiffs at a disadvantage in examining these defendants as well as witnesses; as to them the narrow New York rules for discovery, see note 32 supra, would still apply. In the spirit of the Mottolese opinion, however, a showing of a need to examine these individuals should move the district judge to allow their examination in the federal action.

34. "The expense of depositions may be exploited most easily in suits such as derivative stockholders' actions. Here, of course, the availability of evidence to a plaintiff from other sources is so limited that depositions are most essential to successful prosecution. Nonetheless, abuse can arise when the imminence of expensive depositions is used for shake-down purposes by plaintiffs who have no intention of pursuing their suits through to trial. The expense of pre-trial examination in such cases can be so large in comparison to the recovery sought that settlement would be almost mandatory." Comment, Tactical Use and Abuse of Depositions under the Federal Rules, 59 YALE L.J. 117, 128-9 (1949). See id. at 128 n.52, 129 n.54. Taking of depositions may also be uscd needlessly to delay proceedings or to harry the deponent by incessant, irrelevant questioning with a similar tendency to force an unfair settlement. Id. at 131-2, 136.

35. See note 17 supra. One can infer that the attorneys in the Mottolese case were only seeking to exploit possible advantages of multiple litigation. Had they merely desired a federal trial, it seems probable that the federal suit could have been brought initially, particularly since such an action was filed under their guidance less than three weelss after the first state suit was begun. Ibid.

36. A stay modified as in the Mottolese case encourages these double actions in at least four respects. First, any expenses of the federal action other than those incurred in taking depositions are eliminated. Second, the multiple suitor is assured that no earlier federal decision will deprive him of the advantages of state trial. Third, the plaintiff is 
seeking an out-of-court shakedown settlement, for example, may avoid the important federal safeguards which protect his fellow class membersthe requirements of advance notice to class members and court approval of all compromises. ${ }^{37}$ Finally, it is an unwarranted extension of concurrent jurisdiction to allow a party to a state court action to bring a duplicate suit in the federal courts with the effect that the Federal Rules as to discovery are made available. Those rules were adopted for use in the federal courts, not as an adjunct to state actions. ${ }^{33} \mathrm{By}$ substituting federal for state procedure the federal court effectively supplants the state's legislative will with its own. ${ }^{39}$ Whenever a federal court wishes to preserve the advantage

enabled to take depositions when most convenient in terms of the state procecding, whereas federal discovery must commonly appear necessary when taken to the prosecution of a federal action. See note 38 infra. Finally, federal depositions may now be used as evidence in the state court, see page 986 sipra.

A plaintiff may have various reasons for seeking to avoid a full federal action. He may shun the more simple and efficient federal practice because his best chance for success lies in tripping his opponent procedurally; or he may fear the effect upon the jury of a federal judge's penetrating commentary on the evidence; or perhaps the state judge is known to be more partial to the plaintiff's side than is the federal judge. See note 37 infra and accompanying text. Generally, it would seem in the public interest and only fair to the adversary that a party procuring benefits of federal jurisdiction should be subjected to its limitations as weil.

37. See FED. R. Crv. P. 23(c). This is an important protection since abusive settlements and dismissals frequently leave the body of stockholders shorn of all rights. See notes 29 and 30 supra and 3 MLoore, Federal. Practice 3549-51, 3559-60 (2d ed. 1948). Yet the rule has no counterpart in some state jurisdictions. See Note, 54 Hanv. L. Rev. 833, 837-8 (1941). In such jurisdictions, the Afottolese-type stay assures complete evasion of this protection while simultaneously making available a procedural instrument frequently abused in stockholder suits. See note 34 supra.

The New York courts have apparently evolved a notice procedure although there is no statute or mandatory rule of court requiring it. See Hornstein, New Aspects of Stockholders' Derivative Suits, 47 CoL. L. Rev. 1, 20-21 (1947). Since the custom lacks the compulsion of law, however, there is some merit in Judge Frank's criticism of the Mottolese stay on the ground that non-party shareholders are afforded less protection under New York practice than in the federal forum. 176 F.2d 301, 309 (2d Cir. 1949) (dissenting opinion).

38. See Bachrach v. General Investment Corp., 31 F. Supp. 84 (S.D.N.Y. 1940) (deposition disallowed where parallel derivative shareholder action in state court): "It is a reasonable interpretation of Rule 26(a) that its purpose is to authorize the talsing of a deposition in an action pending in this Court either to make discovery in preparation for, or to be used as evidence upon the trial of, such action.

"... This [taking of federal depositions in aid of state litigation] does not appeas to me to be within the letter or spirit of the new Federal Rules of Civil Procedure" See also Snap Iite Corp. v. Stewart Warner Corp., 40 F. Supp. 776 (S.D.N.Y. 1941) (same holding); see Empire Liquor Corp. v. Gibson Distilling Co., 2 F.R.D. 247, 248 (S.D.N.Y. 1941) ; De Seversky v. Republic Aviation Corp., 2 F.R.D. 183, 185 (E.D.N.Y. 1941). Contra: Milier-Beck Co. v. MfacGowan, 13 F.R.S. 30b.31, Case 2 (S.D.N.Y. 1949) (deposition permitted though its only purpose was to aid preparation for state actions).

39. The federal court is unwilling to permit a similar influencing of its procedure 
of federal discovery machinery, therefore, it should allow the action to proceed rather than grant a modified stay.

But even where plaintiff's advantages in a federal proceeding may be substantial, the federal courts should follow the general practice of granting a stay whenever a state action already in process involves identical parties and issues. ${ }^{40}$ The common dangers in concurrent proceedings-wasted judicial energies, unnecessary burdening of 'defendants, and jockeying for favorable trial positions-create a strong presumption in favor of such practice. ${ }^{41}$ Other considerations lend further weight. An individual plaintiff in a state court should not be permitted to avoid the effects of his choice of forum by bringing a later federal suit on the same cause. ${ }^{42}$ Allowing the second suit affords a method for effectively defeating the federal removal provision which allows only defendants to remove disputes to the federal courts. ${ }^{43}$ Similarly, the state-court defendant who might have a separate claim against his opponent in the first suit should not be allowed to bring an independent federal action involving the same issues. Having had an equal chance to launch the first attack, he should be bound, just as the state-court plaintiff is, by the plaintiff's choice of forum. This is especially true where the state-court plaintiff; cannot practicably engage in twin contests because

by state courts: depositions taken in a pending state proceeding are apparently inadmissible in a federal action involving the same parties and issues. See FEv. R. Civ. P. 26 (a) ; 2 Moore, Federal Practice $\$ 26.08$ (1st ed. 1938). Cf. Atlantic Leasing Co. v. Gen. Outdoor Adv. Co., 4 F.R.D. 122 (S.D.N.Y. 1943). Of course, such state depositions may still influence the federal proceeding by uncovering valuable cvidence.

40. The federal action may raise issues not posed in the original suit though related to the same subject matter. But this should not be a means of evading a stay where the issues could reasonably have been raised by amending the pleadings in the state proceeding. See Ciark, Code Pleading \$\$ 115, 117 (2d ed. 1947).

The federal action may also contain separate controversies unrelated to the state proceedings. See the liberal provisions for permissive counterclaims, cross-claims, third party practice, and joinder of parties and issues, FED. R. Crv. P. 13(a-h), 14, 18, 19, 20(a). However, a stay of the controversy which is matched in the state action should still be possible because the unmatched controversies can be tried separately in the federal court. FED. R. Cw. P. 42(b), 21, 20(b), 13(i), 54(b).

41. Such a course would harmonize with present Supreme Court deference to stato autonomy, see page 981 and note 11 supra, by avoiding the possibility of rendering state judicial operations ineffectual. It is significant that in cases requiring parties to seck: relief in the state courts, see notes 11 and 12 stipra, availability there of procedire and speedy adjudication equivalent to that in the federal forum has not been a condition precedent to refusal of federal jurisdiction:

42. The probability of abuse is apparent, for advantages of federal jurisdiction can be anticipated before the first suit is filed. The plaintiff should fare no better than a party who brings his second action in the same state or federal jurisdiction; such suits are abated as a matter of course. See notes 1 and 4 supra.

43. 28 U.S.C. \$1441(a) (1949). See MLore, Judicial Code Comaentaky 221-2 (1949). 
of limited funds or the smallness of his claim.4 A second suit would then effectively deprive the plaintiff of his original choice of forum. ${ }^{45}$

Ready granting of stays seems equally applicable to shareholder derivative suits and similar class actions. Shareholder plaintiffs should be as bound by the original choice of forum as any private plaintiff. ${ }^{40}$ The situation reflected in the Mottolese case where both state and federal actions are under common control is pregnant with possibilities for abuse of concurrent jurisdiction. ${ }^{47}$ But even where the later federal action is not under the same control as the state suit a stay should usually be ordered unless the subsequent action is necessary for adequate representation of shareholder interests. It is unfair to allow the second plaintiff, who has perhaps plagiarized the. state-court plaintiff's complaint, ${ }^{48}$ to reach an earlier judgment which would thereby deprive the first plaintiff of the opportunity to obtain sizeable counsel fees. ${ }^{49}$ The award of such fees is a major inducement to the diligent

44. See note 22 sipra.

45. Allowing the defendant to bring the federal suit also circumvents the requirements for removal, see note 43 supra. A controversy which would otherwise be tried only in the state court is, in substance, thereby transferred to the federal forum.

46. The real plaintiff-in-interest, the corporation, is already a party to the state proceeding. And the right of one among numerous stockholders to choose a particular forum may properly be given less weight than the same right of a party suing on his individual claim. See Koster v. Lumbermens Casualty Co., 330 U.S. 518, 522-6 (1947).

47. See note 35 supra. The ability to enter both forums on the same cause of action should be especially conducive to strike suits aimed at blackjaching defendants into settling for the nuisance value of the litigation. See Balrantros, op. cit. supra note 31, $\$ 149$. Shakedown suits involving legitimate claims, see note 29 sipra, would likewise be encouraged by the prospect of a more handsome settlement resulting from the burden of an additional suit.

Where the same attorneys in parallel derivative actions represent nominally difierent plaintiffs, their common control is likely to have fostered the dual pattern; lawyers do not always abide scrupulously by the requirement that a client procure initiation of the action. See Kalven \& Rosenfield, The Contemporary Fusuction of the Class Sutit, 8 U. OF CHI. L. Rev. 684, 717-18, n.98 (1941). Presence of common attorneys is not, of course, a prerequisite for the abuse of double derivative suits-individual stocldholders or their separate legal representatives may also cooperate.

48. The original complaint, being a readily accessible public record, may be easily copied: Such plagiarism is highly unfair. Usually the wrongdoing at issue involves complex transactions which only experts can unravel. Necessary information must be gleaned from hostile corporate sources. Consequently, a considerable outlay of time and expense will normally be necessary in procuring enough facts to state a valid cause of action. See Hornstein, Legal Controls for Intracorporate Absus-Present and Future, 41 CoL. I. REv. 405, 416-22 (1941).

Plaintiffs frequently guard against suits based on plagiarism of their complaint by purposely filing duplicate actions in federal and state courts. See Miller-Beck Co. v. MacGowan, 13 F.R.S. 30b.31, Case 2, p. 28 (S.D.N.Y. 1949).

49. The shareholder who undertakes a suit for the benefit of all stocksholders does so at the risk of considerable personal loss. See Hornstein, The Counsel Fee in Stockholder's Derivative Suits, 39 CoL. L. REv. 784, 791-3 (1939); Hornstein, Legal Conlrols for Intracorporate Abuse-Present and Future, 41 CoL L. Rev. 405, 427-S (1941). Yet 
prosecution of derivative actions. ${ }^{50}$ In view of the importance of derivative suits to the effective policing of corporate management, ${ }^{, 1}$ this incentive should not be dampened.

The practice of granting stays might also be appropriate to federal proceedings which include some but not all of the issues and parties present in the state court. Thus, a stay would seem proper in most cases where the additional issues, ${ }^{52}$ such as amount of damages, and additional parties, such as sureties, are incidental to the main controversy. ${ }^{\mathrm{b}}$

There may be exceptional circumstances, however, where a federal suit, though identical with a prior state suit both as to issues and parties, should nevertheless be allowed to continue. For example, a federal suit should not be stayed where a derivative or other class action in a state court is not being prosecuted effectively, and intervention by the new federal plaintif in a state proceeding is impossible or would not give adequate protection to the

even if the "suit is successful, his proportional interest as shareholder in the recovery will normally be less than the expenses of litigation. The liberal award of counsel fees and expenses made from the fund recovered is, therefore, his one means of recouping his expenditures. See Ballantine, Corporations $\$ 149$ (rev. ed. 1946); Hornstcin, New Aspects of Stockholders' Derivative Suits, 47 Cor. L. REv. 1, 24-30 (1947) ; Hornstein, The Counsel Fee in Stockholder's Derivative Suits, 39 CoL. L. REv. 784, 791 (1939). Hence it seems patently unfair to allow another stockholder to eliminate all opportunity for recovering these fees by reaching an earlier decision in a subsequent fedcral action. Often the sole purpose of this second suit will be to grab the award.

50. See Baltantine, Corporations $\$ 156$ (rev. ed. 1946); Hornstein, The Cominsel Fee in Stockholder's Derivative Suits, 39 CoL. L. REv. 784, 791-815 (1939). Sce note 49 supra. The same is true of class suits generally. See Kalven \& Rosenficld, sttpra note 47 , at $715-17$.

51. See Ballantine, Corporations \$149 (rev. ed. 1946); McLaughlin, supra note 30, at 423; Hornstein, New Aspects of Stockholders' Derivative Suits, 47 CoL. L. Rev. 1, 31 (1947).

52. As observed in note 40 supra, additional issues which could have been raised by amendment in the state proceeding should be treated as though in fact raised there.

53. See De La Vergne Mach. Co. v. New York \& B. Brewing Co., 125 App. Div. 649, 650, 110 N.Y. Supp. 24, 25 (2d Dep't 1908). Or, if federal suit by the state-court defendant would be disposed of by a decision in the state contest favoring his opponent, then sound discretion might call for a stay. For example, both suits may be brought for injuries received in an automobile accident, the only substantial issues in each case being the negligence of the parties. A general verdict for plaintiff in the state court would establish the federal plaintiff's contributory negligence by collateral estoppel. An opposite verdict, on the other hand, would leave the question of the federal defendant's negligence to be determined in the federal action.

The ability to have raised the extra issues by counterclaim in the state court, sce Clark, Code Pleading $\$ \$ 101-106$ (2d ed. 1947), weighs heavily in favor of a stay: the federal court should not needlessly sanction departure from its general principle, see FED. R. CTV. P. 13(a) (compulsory counterclaim), of completely disposing of all issues of a dispute in a single action. Other considerations here relevant would include: the diligence with which the state action was being pressed, the importance of the claims involved, the character of benefits of federal jurisdiction, the burdens imposed on the defendant, plaintiff's delay in bringing the second suit. 